\title{
Overcoming methamphetamine withdrawal syndrome through cognitive behavioural therapy in female correctional inmates
}

\author{
Khirza Maulida Fitri' ${ }^{1}$, Rita Hadi Widyastuti ${ }^{1}$
}

1 Nursing Department, Medicine Faculty, Universitas Diponegoro, Indonesia

\begin{tabular}{|c|c|}
\hline Article Info & Abstract \\
\hline $\begin{array}{l}\text { Article History: } \\
\text { Submitted: Sept } 14^{\text {th }}, 2021 \\
\text { Accepted: Nov } 10^{\text {th }}, 2021 \\
\text { Published: Nov } 25^{\text {th }}, 2021 \\
\text { Keywords: } \\
\text { Withdrawal syndrome; } \\
\text { Cognitive behavioral } \\
\text { therapy; Female inmates }\end{array}$ & $\begin{array}{l}\text { Cognitive-behavioural therapy (CBT) approaches have among the highest } \\
\text { level of empirical support for drug and alcohol use disorder treatment. The } \\
\text { unbearable impact of withdrawal syndrome such as physical related } \\
\text { problems, psychological, social and behavioural can take a long-term impact } \\
\text { such as affective and anxiety disorder that can lead to depression. CBT as an } \\
\text { intervention that improves coping-skill, and strategy to change a } \\
\text { maladaptive mindset should be convenient to reduce withdrawal symptoms. } \\
\text { The effect of CBT intervention on the severity of the symptoms of } \\
\text { methamphetamine withdrawal syndrome is still narrow. This research is } \\
\text { aimed to find out the CBT effect on withdrawal symptoms in both qualitative } \\
\text { and quantitative methods on female inmates. This research uses a case study } \\
\text { design. Data were conducted using Amphetamine Withdrawal } \\
\text { Questionnaire (AWQ) before and after CBT intervention. Data were analyzed } \\
\text { using univariate analysis presented as distribution frequency on both before } \\
\text { and after the intervention and discussed with single case analysis. The result } \\
\text { showed that CBT affects reducing withdrawal syndrome symptoms severity } \\
\text { after } 4 \text { weeks and } 4 \text { session intervention. CBT affects decreasing withdrawal } \\
\text { syndrome severity level. Based on these findings, the correctional nurse } \\
\text { needs to develop comprehensive nursing care by providing CBT on a } \\
\text { rehabilitation program to decrease female inmates' withdrawal syndrome } \\
\text { severity level. }\end{array}$ \\
\hline
\end{tabular}

\section{PENDAHULUAN}

Penghentian narkotika dan zat adiktif secara tiba-tiba setelah penggunaan dalam jangka waktu lama terbukti dapat menimbulkan berbagai permasalahan yang berhubungan dengan kondisi fisik, psikologis, sosial dan perilaku [1-4]. Kumpulan dari gejala fisik maupun psikologis yang terjadi setelah penghentian narkotika dan zat adiktif dikenal dengan withdrawal syndrome atau sindrom putus- zat $[5,6]$. Menurut penelitian yang dilakukan oleh Mc. Gregor et al (2008), mengemukakan bahwa sebanyak $97 \%$ dari total responden yang teridentifikasi menggunakan amfetamin secara rutin mengalami gejala sindrom putus zat saat penghentian penggunaan $[7,8]$. Penelitian lain yang dilakukan oleh Vik (2007), menyebutkan bahwa $45 \%$ dari WBP perempuan memiliki ketergantungan lebih dari 2 jenis zat adiktif, $53 \%$ mengalami gangguan afektif dan $46 \%$ mengalami

Corresponding author:

Rita Hadi Widyastuti

ritahadi@fk.undip.ac.id

Media Keperawatan Indonesia, Vol 4 No 4, November 2021

e-ISSN: 2615-1669

ISSN: 2722-2802

DOI: $10.26714 /$ mki.4.4.2021.323-329 
gangguan kecemasan yang dapat mengarah pada depresi[9]. Terjadinya sindrom putus zat pada WBP diakibatkan oleh perubahan status menjadi narapidana sehingga tidak adanya akses untuk mendapatkan zat tersebut di dalam lapas dan kurangnya perhatian dari petugas megenai dampak putus zat $[10,11]$.

Hasil wawancara dan penyaringan yang telah dilakukan pada petugas dan WBP didapatkan hampir dari seluruh WBP perempuan di LPM klas IIA pengguna narkotika dan zat adiktif pernah mengalami sindrom putus zat dengan jangka waktu yang berbeda-beda tiap individu, tergantung jangka waktu penggunaannya. Permasalahan yang biasanya timbul dapat berupa gejala fisik seperti pusing, mual maupun gangguan tidur, sedangkan gejala psikologis berupa rasa malas dan gelisah $[10,12,13]$. Sesuai dengan Undang-Undang Narkotika Nomor 35 tahun 2009 pasal 54, pecandu narkotika dan korban penyalahgunaan narkotika diwajibkan untuk menjalani rehabilitasi medis dan sosial. Dalam ranah hukum, bagian kesehatan pada lembaga pemasyarakatan berperan dalam melakukan screening tingkat ketergantungan, merekomendasikan rencana terapi dan rehabilitasi bagi WBP pengguna narkotika dan zat adiktif dengan bekerjasama dengan BNN [4]. Penanganan yang telah dilakukan di lapas yaitu pemberian obat untuk meringankan gejala fisik yang dialami oleh WBP dan kegiatan rehabilitasi rutin yang diikuti oleh WBP tergabung dalam kelompok rehabilitasi. Hasil dari penanganan tersebut belum maksimal dikarenakan hanya mengurangi gejala fisik dalam waktu tertentu dan kegiatan rehabilitasi yang dilakukan belum dapat mencangkup keseluruhan WBP yang mengalami gejala sindrom putus zat. Masih terdapat WBP yang terindikasi mengalami gejala sindrom putus zat kategori berat yang tidak mengikuti kegiatan rehabilitasi sehingga dibutuhkan pemberian intervensi.
Intervensi yang dapat digunakan untuk menurunkan keparahan sindrom putus zat pada WBP perempuan yaitu Cognitive Behavioural Therapy (CBT). CBT dipilih oleh peneliti karena merupakan intervensi psikologis teraupetik yang terstruktur yang dapat digunakan untuk mengatasi masalah dengan target kognitif, afektif dan situasi yang dapat memicu timbulnya keinginan untuk menggunakan metamfetamin dengan menitik beratkan pada melatih skill positif dan alternatif koping dengan tetap disesuaikan kondisi partisipan [14-16]. Intervensi CBT telah banyak dilakukan untuk mengurangi ketergantungan zat adiktif salah satunya pada penelitian yang dilakukan oleh Jalali, Hashemi dan Hasani (2018) yang membuktikan bahwa CBT dapat mengurangi ketergantungan [15]. CBT juga terbukti dapat menurunkan angka kecemasan dan depresi serta meningkatkan harga diri pada pecandu dengan sindrom putus zat $[7,9,13,17]$. Intervensi CBT terhadap gejala sindrom putus zat akan berjalan efektif apabila diikuti pengontrolan teratur, penyesuaian suasana hati, informasi dan lingkungan yang sesuai. Dukungan dari lingkungan merupakan kunci dari kemampuan partisipan untuk mempertahankan motivasinya dalam berubah dan menyelesaikan masa sindromnya. Keterbatasan tenaga kesehatan di lapas dan belum adanya kebijakan khusus menjadi tantangan keberhasilan intervensi tersebut $[12,15]$.

Penelitian mengenai dampak CBT terhadap gejala pada sindrom putus zat pada narapidana di Indonesia belum banyak diteliti baik secara kualitatif maupun kuantitatif. Penelitian yang banyak dilakukan di Indonesia masih luas cakupannya salah satunya penelitian yang dilakukan oleh Hairina dan Komalasari (2017) mengenai kondisi psikologis narapidana di lapas yang dikaitkan dengan riwayat penggunaan narkotika [3]. Penelitian sebelumnya juga dilakukan di Iran oleh Jalali, Hashemi dan Hasani (2018) mengenai dampak grup terapi CBT untuk menurunkan keinginan konsumsi atau 
craving pada pengguna metamfetamin dengan HIV/AIDS [15]. Belum adanya penelitian mengenai gejala fisik, psikologis dan penelitian yang spesifik terkait intervensi sindrom putus zat pada narapidana pengguna narkotika membuat peneliti ingin menganalisis lebih lanjut terkait pengaruh CBT terhadap gejala sindrom putus zat WBP perempuan pada masing-masing item. Penelitian tersebut penting bagi perawat untuk mengembangkan intervensi pada asuhan keperawatan guna mengatasi keparahan sindrom putus zat pada WBP perempuan.

\section{METODE}

Penelitian ini merupakan penelitian dengan desain studi kasus. Populasi dalam penelitian ini adalah seluruh WBP perempuan di Lembaga Pemasyarakatan Wanita Klas II A Semarang. Sampel penelitian ini sebanyak satu partisipan yang dipilih melalui teknik convenience sampling dengan kriteria inklusi bersedia mengikuti rangkaian penelitian, teridentifikasi mengalami sindrom putus zat kategori ringan hingga berat, termasuk narapidana yang baru menjalani masa tahanan kurang dari 6 bulan, menolak mengikuti program rehabilitasi dari lapas, kooperatif, dan mampu berkomunikasi dengan baik.

Pengumpulan data menggunakan kuesioner Amphetamine Withdrawal Questionnaire (AWQ). Kuesioner AWQ terdiri dari 10 pertanyaan yang berfungsi untuk mengukur gejala putus zat amfetamin dengan hasil perhitungan dalam rentang skor 0-40 yang menggambarkaan semakin berat gejalanya. Kuesioner AWQ merupakan kuesioner baku yang telah terbukti valid dan reliabel. Hasil uji validitas dengan nilai alpha $(\alpha)$ sebesar 0,77 dan uji reliabilitas dengan total skor korelasi 0,79 sehingga kuesioner ini dinyatakan valid dan reliabel untuk digunaka [18].

Proses penelitian dimulai dengan identifikasi partisipan sesuai kriteria inklusi kemudian dilanjutkan intervensi
CBT yang terdiri dari 4 sesi yang berfokus pada peningkatan kemampuan untuk mengurangi gejala putus zat metamfetamin dengan waktu intervensi selama 45-60 menit setiap pertemuannya [12]. Diadopsi dari penelitian sebelumnya oleh Jalali, Hashemi dan Hasani (2018) CBT dalam penelitian ini dilakukan secara individual selama empat minggu dengan minimal satu kali pertemuan setiap minggunya. Mekanisme CBT dalam penelitian ini yaitu partisipan menjalani 4 sesi intervensi yang disesuaikan dengan stage ketergantungan saat ini $[12,15]$.

Sesi pertama CBT yaitu melakukan wawancara motivasional untuk mengetahui membangun motivasi, menguatkan komitmen untuk berubah dan pengawasan diri. Sesi ke dua berisi pemberian informasi mengenai suggest, berbagi pengalaman suggest dan cara mengatasi keinginan penggunaan zat kembali dengan strategi koping. Sesi ke tiga yaitu mengenai kontrol pikiran dengan mengidentifikasi pikiran negatif dan keraguan dalam mengambil keputusan serta pembuatan jadwal mingguan. Sesi ke empat yaitu pencegahan relaps dengan melihat kemampuan partisipan dalam penolakan penggunaan zat dibantu dengan role play dan dilanjutkan dengan terminasi yang berisi konfirmasi ulang mengenai komitmen pada sesi pertama, membuat kalimat motivasi dan evaluasi dengan pengisian ulang kuesioner AWQ [7,12,15,19].

Analisis data menggunakan analisa univariat yang disajikan dalam bentuk distribusi frekuensi sebelum dan sesudah pemberian intervensi CBT yang kemudian dibahas dengan single case analysis. Single case analysis adalah analisa kasus yang berfokus untuk menganalisa satu permasalahan pada partisipan yaitu gejala sindrom putus zat metamfetamin. Analisa data yang diskripsikan meliputi item pertanyaan kuesioner AWQ yang mengalami peningkatan signifikan setelah diberikan intervensi CBT [20]. 


\section{HASIL}

Hasil analisa menunjukkan bahwa terdapat penurunan skor gejala sindrom putus zat setelah dilakukan CBT. Perubahan yang signifikan terjadi pada item keinginan konsumsi dan penurunan energi. Skor awal menunjukkan skor 4 yang berarti partisipan merasa sangat ingin mengkonsumsi metamfetamin. Setelah dilakukan intervensi CBT selama 4 sesi dalam 4 minggu maka terjadi penurunan skor menjadi 2 yang berarti partisipan mengalami sedikit keinginan untuk mengkonsumsi metamfetamin. Perubahan gejala sindrom putus zat partisipan dimunculkan dalam gejala dan penurunan rank-score yang bervariasi pada setiap domain yang digambarkan pada tabel 1 .
Tabel 1

Perubahan Gejala Sindrom Putus Zat WBP

Perempuan Sebelum dan Sesudah CBT $(\mathrm{n}=1)$

\begin{tabular}{lcc}
\hline $\begin{array}{c}\text { Gejala Sindrom Putus Zat } \\
\text { Amfetamin }\end{array}$ & $\begin{array}{c}\text { Pre- } \\
\text { test }\end{array}$ & $\begin{array}{c}\text { Post- } \\
\text { test }\end{array}$ \\
\hline Keinginan konsumsi & 4 & 2 \\
Disforia & 3 & 2 \\
Kehilangan minat atau & 3 & 2 \\
kesenangan & & \\
Kecemasan & 3 & 3 \\
Pergerakan lambat & 3 & 2 \\
Perasaan gelisah & 3 & 2 \\
Penurunan energi & 4 & 2 \\
Pengingkatan nafsu makan & 3 & 2 \\
Mimpi buruk atau terasa nyata & 3 & 2 \\
Perasaan sering mengantuk & 3 & 3 \\
\hline
\end{tabular}

Tabel 2.

Hasil Observasi Respon Partisipan pada Setiap Sesi CBT

\section{Sesi CBT}

Sesi 1:

Wawancara

motivasional

\section{Respon}

Partisipan mengatakan tidak betah tinggal di lapas dan ingin pulang karena merindukan keluarga, anak dan sabunya. Partisipan mengatakan motivasi terbesarnya saat ini adalah masa depan anaknya dan tidak ingin anaknya mengikuti jejak orang tuanya. Partisipan mengatakan berhenti menggunakan sabu selama ditahan, namun merasa belum dapat membuat komitmen terkait penggunaan sabu kembali setelah bebas. Partisipan mampu terbuka pada peneliti terkait permasalahan putus obat yang diderita saat ini, dapat menyebutkan dampak positif dan negatif terkait penggunaan sabu serta dapat mencertiakan pengalamannya selama menggunakan sabu.

Sesi 2:

Mengatasi keinginan dan lapse dengan strategi koping

Partisipan dapat mendiskripsikan peristiwa suggest yang dialami dan mampu mengidentifikasi bahwa suggest terjadi saat menelpon teman yang sedang menggunakan sabu. Partisipan mampu menyebutkan koping yang dapat dilakukan untuk mengalihkan suggest menurunkan keinginan konsumsi pada WBP dengan sindrom putus zat dengan menentukan koping positif yang dapat digunakan yaitu menyibukkan diri di bimker atau tidur. Partisipan belum dapat membuat komitmen untuk berhenti menggunakan sabu setelah bebas.

Sesi 3: Kontrol Partisipan mengungkapkan pikiran pemicu terjadinya suggest yaitu teringat pengalaman masa pikiran lalu saat menggunakan sabu. Partisipan menyebutkan kondisi berisiko tinggi dan mengungkapkan alternative yang dapat dilakukan untuk mengatasi lapse dalam kondisi tersebut yaitu dengan menutup telpon atau tidak membukakan pintu rumah untuk teman yang dianggap merugikan. Partisipan dibantu oleh peneliti mampu membuat jadwal kegiatan yang menyenangkan untuk satu minggu kedepan. Partisipan dapat membuat rencana alternatif yang dapat dilakukan saat muncul pikiran negatif serta mengidentifikasi penyebab munculnya pikiran tersebut. Partisipan mampu menggunakan pembelajaran kemampuan pemecahan masalah pada keadaan risiko tinggi dan kemampuan pemecahan masalah cenderung lebih diterima pada ranah sosial. Pembuatan jadwal harian juga membantu partisipan menganalisa minat dan kesenangan yang dapat dilakukan sehingga menjadikan kegiatan keseharian lebih terstruktur.

Sesi 4:

Pencegahan relaps dan evaluasi asertif namun belum maksimal. Partisipan mampu mereview kembali kegiatan menyenangkan yang telah direncanakan selama satu minggu kedepan. Partisipan mampu berkomitmen untuk tidak mengkonsumsi sabu setelah bebas dan memilih untuk mengedarkan saja. Partisipan mengungkapkan merasa lebih lega dan betah menjalani kehidupan di lapas karena kebutuhan spiritualnya lebih terpenuhi. 
Hasil analisa menunjukkan bahwa terdapat perubahan respon setelah dilakukan CBT. Perubahan yang signifikan terjadi pada Keinginan konsumsi dapat menurun karena pada sesi ke 2 intervensi CBT yaitu mengatasi keinginan dengan strategi koping. Hasil Observasi respon partisipan pada setiap sesi CBT diuraikan pada tabel 2 .

\section{PEMBAHASAN}

Hasil penelitian ini menunjukkan bahwa pemberian intervensi CBT dapat menurunkan skor gejala sindrom putus zat metamfetamin pada WBP perempuan. Hasil penelitian sesuai dengan penelitian yang dilakukan oleh Jalali, Hashemi dan Hasani (2018) yang menyebutkan bahwa setelah diberikan intervensi CBT selama 4 minggu terjadi penurunan tingkat keinginan konsumsi atau craving pada partisipan dengan penggunaan kronis metamfetamin yang tidak mendapatkan psikoterapi secara simultan. Penelitian lain yang dilakukan oleh Taylor et al 2018 (2018), menyebutkan bahwa CBT secara rutin dengan pertemuan minimal satu kali setiap minggunya dapat menurunkan gejala putus zat amfetamin seperti gelisah, cemas, tidak memiliki rasa ketertarikan pada sesuatu dan sulit tidur [21,22].

Penurunan skor gejala sidrom putus zat dari 32 (gejala sindrom berat) menjadi 22 (gejala sindrom sedang) terjadi setelah diberikan intervensi CBT. Pada pengkajian awal, partisipan cenderung medapatkan skor tinggi pada seluruh gejala sindrom putus zat dan mengalami penurunan setelah diberikan intervensi CBT selama 4 sesi. Perubahan signifikan muncul pada item nomor 1 yaitu keinginan konsumsi dan item nomor 7 yaitu penurunan energi. Pada pengkajian awal partisipan mengatakan memiliki keinginan yang sangat besar untuk mengkonsumsi metamfetamin dan mengalami penurunan energi sehingga merasa malas dan pergerakannya lambat. Gejala lain yang menyertai saat keinginan konsumsi muncul berupa disforia, perasaan gelisah dan mimpi buruk. Hasil tersebut sesuai dengan penelitian yang dilakukan oleh Jalali, Hashemi dan Hasani (2018) yang menyebutkan bahwa keinginan konsumsi atau craving merupakan faktor paling penting dalam mempertahankan ketergantungan zat dan relapse. Apabila keinginan konsumsi tidak terpenuhi maka partisipan akan mengalami perubahan pada psikologis dan fisiknya seperti kelemahan, rasa mual, kecemasan, insomnia, agresi dan depresi $[12,15]$.

Intervensi CBT terbukti dapat menurunkan keinginan konsumsi pada WBP dengan sindrom putus zat dengan merubah strategi koping menjadi lebih efektif sehingga dapat mengurangi risiko craving dan relapse dibandingkan dengan kelompok yang tidak diberikan intervensi [15]. Keinginan konsumsi dapat menurun karena pada sesi ke 2 intervensi CBT yaitu mengatasi keinginan dengan strategi koping. Sesi ini berfokus pada penguatan motivasi untuk mempertahankan penghentian penggunaan metamfetamin dan pencegahan lapse dengan menggunakan strategi koping yang telah disepakati bersama partisipan. Peneliti bersama partisipan mendiskusikan cara untuk menghadapi cravings, strategi yang dapat dilakukan saat keinginan muncul dengan konsep 3Ds (delay, distract, decide). Setelah melalui fase ini, partisipan mampu menjelaskan cara menyikapi lapse dan memikirkan tindakan yang sesuai saat terjadi tanda-tanda lapse $[12,13]$.

Indikator dari gejala sindrom putus zat lain yang mengalami penurunan skor namun kurang signifikan yaitu pada item kehilangan minat atau kesenangan dan peningkatan nafsu makan. Pecandu narkotika dengan gejala sindrom putus zat cenderung akan menggunakan emosi negatif dan kembali menggunakan zat daripada menggunakan strategi yang berfokus pada masalah saat tertekan [9].

Intervensi CBT terbukti mampu menurunkan gejala sindrom putus zat berupa kehilangan minat dan peningkatan nafsu makan karena pada sesi ke 3 terdapat 
intervensi CBT kontrol pikiran yang bertujuan untuk mengidentifikasi adanya pikiran negatif dan keraguan partisipan dalam mengambil keputusan. Pada sesi ini peneliti menjelaskan kepada partisipan mengenai model siklus (pikiran-perasaanperilaku) untuk menekankan bahwa pikiran dapat mempengaruhi perilaku $[12,13]$. Partisipan dapat membuat rencana alternatif yang dapat dilakukan saat muncul pikiran negatif serta mengidentifikasi penyebab munculnya pikiran tersebut. Partisipan mampu menggunakan pembelajaran kemampuan pemecahan masalah pada keadaan risiko tinggi dan kemampuan pemecahan masalah cenderung lebih diterima pada ranah sosial. Pembuatan jadwal harian juga membantu partisipan menganalisa minat dan kesenangan yang dapat dilakukan sehingga menjadikan kegiatan keseharian lebih terstruktur. Peningkatan nafsu makan terjadi saat partisipan tidak mampu mengontrol dirinya sehinga kontrol pikiran dan regulasi diri dapat mengrontrol perasaan dan emosi partisipan $[9,12,15]$.

\section{SIMPULAN}

WBP dengan putus zat metamfetamin dapat mengalami berbagai permasalahan yang berhubungan dengan kondisi fisik, psikologis, sosial dan perilaku. CBT berpengaruh terhadap penurunan gejala sindrom putus zat metamfetamin pada WBP perempuan dari keparahan berat menjadi keparahan sedang. CBT membantu menurunkan gejala putus zat metamfetamin dengan memperkenalkan keterampilan koping dan strategi kognitif baru untuk mengubah pola perilaku dan pola pikir mal adaptif. Oleh karena itu, perawat Lapas perlu mengembangkan asuhan keperawatan komprehensif meliputi bio-psiko-sosio-kultural-spiritual dengan melakukan skrining gejala sindrom putus zat dan pemberian intervensi CBT dalam kegiatan rehabilitasi untuk menurunkan gejala putus zat yang dialami WBP perempuan. Peneliti merekomendasikan pada peneliti selanjutnya untuk mengembangkan penelitian dengan subjek penelitian yang lebih luas.

\section{UCAPAN TERIMAKASIH}

Kepada semua pihak yang telah membantu dan mendukung dalam studi kasus ini kami mengucapkan terimakasih atas perhatian dan dukungannya.

\section{REFERENSI}

[1] Joe GW, Rowan-Szal GA, Greener JM, Dwayne Simpson D, Vance J. Male MethamphetamineUser Inmates in Prison Treatment: During Treatment Outcomes. J Subst Abus Treat 2010;38.

https://doi.org/10.1016/j.jsat.2009.08.002.Ma le.

[2] Adiyanti MG. Inisiasi Ketangguhan Masyarakat dalam Mengatasi Adiksi NAPZA: Menelaah Program Rehabilitasi Initiation of Community Resilience on Drug Addiction: Exploring Rehabititation Programs 2019;27:87-108. https://doi.org/10.22146/buletinpsikologi.45 890.

[3] Hairina Y, Komalasari S. Kondisi Psikologis Narapidana Narkotika Di Lembaga Permasyarakatan Narkotika Klas II Karang Intan Martapura, Kalimantan Selatan. J Stud Insa 2017;5:94-104. https://doi.org/http://dx.doi.org/10.18592/js i.v5i1.1353.

[4] Kemenkes. Gambararn Umum Penyalashgunaan Narkoba di Indonesia. Bul Jendela Data Dan Inf 2014

[5] WHO. Clinical guidelines for withdrawal management and treatment of drug dependence in closed settings. Manila: WHO Library Cataloguing in Publication Data Clinical; 2009.

[6] NSW H. Guideline Drug and Alcohol Withdrawal Clinical Practice Guidelines - NSW 2008.

[7] Smout M. Psycotherapy for Methamphetamine Dependence: Treatment Manual. March. Gouverment of South Australia; 2008.

[8] Mcgregor C, Clin MP, Ph D, Srisurapanont M, D M, Mitchell A, et al. Psychometric evaluation of the Amphetamine Cessation Symptom Assessment 2008;34:443-9. https://doi.org/10.1016/j.jsat.2007.05.007.

[9] Vik PW. Methamphetamine Use By Incarcerated Women: Comorbis Mood and Anxiety Problem. Women's Heal 2007:256-63. 
https://doi.org/10.1016/j.whi.2006.12.004.

[10] Der-Avakian A, Markou A. Withdrawal from chronic exposure to amphetamine, but not nicotine, leads to an immediate and enduring deficit in motivated behavior without affecting social interaction in rats. Behav Pharmacol 2010;21:359-68.

https://doi.org/10.1097/FBP.0b013e32833c7 cc8.Withdrawal.

[11] Manning V, Gar JBB, Mroz K, Campbell SC, Piercy $\mathrm{H}$, Staiger PK, et al. Journal of Substance Abuse Treatment Feasibility and acceptability of approach bias modi fi cation during methamphetamine withdrawal and related methamphetamine use outcomes 2019;106:12-8. https://doi.org/10.1016/j.jsat.2019.07.008.

[12] Grigg J, Manning V, Arunogiri S, Volpe I, Frei M, Phan V, et al. Methamphetamine Treatment Guidelines: Practice Guidelines for Health Professionals. Second Edi. Victoria: Turning Point; 2018.

[13] Baker A, Kay-Lambkin F, Lee NK, Claire M, Jenner L. A brief cognitive behavioural intervention for regular amphetamine users : A treatment guide. Newcastle: Australian Government Department of Health and Ageing; 2003.

[14] Vujanovic AA, Smith LJ, Green CE, Lane SD, Schmitz JM. Development of a novel, integrated cognitive-behavioral therapy for co-occurring posttraumatic stress and substance use disorders: A pilot randomized clinical trial. Contemp Clin Trials 2018;65:123-9. https://doi.org/10.1016/j.cct.2017.12.013.

[15] Jalali F. The Effectiveness of CognitiveBehavioral Group Therapy in Reducing Craving among Methamphetamine Abusers Living with HIV / AIDS. IMedPub Journals 2018;4:1-8. https://doi.org/10.21767/2471-853X.100076.

[16] Carroll KM, Kiluk BD. Cognitive Behavioral
Interventions for Alcohol and Drug Use Disorders: Through the Stage Model and Back Again. Psychol Addict Behav 2018;31:847-61. https://doi.org/10.1037/adb0000311.Cognitiv e.

[17] Brook S, Fitzgerald L, Selvey L, Maher L. International Journal of Drug Policy Turning points, identity, and social capital: A metaethnography of methamphetamine recovery 2019;67:79-90. https://doi.org/10.1016/j.drugpo.2019.02.002

[18] Srisurapanont M, Jarusuraisin N, Jittiwutikan J. Amphetamine withdrawal: I . Reliability , validity and factor structure of a measure 1998.

[19] Hill R. Evidence-Based Practices for Treatment of Methamphetamine Dependency: A Review. Guleph: Community Enganged Scholarship Institute; 2015.

[20] Yin RK. Case study research and applications: Design and methods. sixth. Los Angeles: SAGE Publication; 2018.

[21] Wolitzky-taylor K, Drazdowski TK, Niles A, Roybyrne P, Ries R, Rawson R, et al. Behaviour Research and Therapy Change in anxiety sensitivity and substance use coping motives as putative mediators of treatment e ffi cacy among substance users. Behav Res Ther 2018;107:34-41.

https://doi.org/10.1016/j.brat.2018.05.010.

[22] Wolitzky-taylor K, Niles AN, Ries R, Krull JL, Rawson R, Roy-byrne P, et al. Behaviour Research and Therapy Who needs more than standard care? Treatment moderators in a randomized clinical trial comparing addiction treatment alone to addiction treatment plus anxiety disorder treatment for comorbid anxiety and substance use disord. Behav Res Ther

2018;107:1-9. https://doi.org/10.1016/j.brat.2018.05.005. 